\title{
CONSUMERS' INTENTIONS TO USE OF ORGANICALLY PRODUCED FOOD IN THE SUMADIJA REGION
}

\author{
Vladislava Stojićl, Mlađan Dimitrijević2, \\ *Corresponding authorE-mail: kgdimasc@gmail.com
}

\begin{abstract}
A R T I C LE IN F O
A B S T R A C T

Review Article

Organic agriculture is a significant factor in sustainable

Received: 03 December 2019

Accepted: 11 March 2020

development, and the production and marketing of organic products tend to grow steadily. The main goal of organic farming is to produce high quality food in doi:10.5937/ekoPolj2001253S UDC 366.1:631.147(497.11 Šumadija) precisely defined conditions. There are great untapped potentials for the development of organic production in Šumadija, thanking to suitable climatic and agro-

Keywords:

consumers' behavior, consumers' intentions, organic food

ecological conditions, knowledge and tradition. The aim of the paper is to investigate the importance and value of organic products according to the opinion of consumers of the Šumadija region, their buying habits, and the source of information about organic products. The results show that JEL: $Q 013$ the consumers are not buying enough organic food, but understand its role in reducing health risks. The general conclusion is that the development of organic production depends on knowledge, awareness of the need to conserve natural resources and the environment, as well as economic factors and incentives for organic production.
\end{abstract}

(C) 2020 EA. All rights reserved.

\section{Introduction}

Quality food is a basic requirement of the modern consumer. Specific agro-technical measures in organic production create conditions for the plants to synthesize and accumulate, under the optimal production conditions, for the type and variety of characteristic matter. The development of organic production and other forms of sustainable agriculture depends on knowledge, awareness of the need to conserve natural resources and the environment, as well as economic factors, markets and incentives for organic production and environmental protection.

The term sustainable agriculture refers to an integrated system of plant and livestock

1 Vladislava Stojić, Assistant, Department of Medical Statistics and Informatics, Faculty of Medical Sciences, University of Kragujevac, Serbia, Phone: +381658817777, E-mail: vladislavastojic@medf.kg.ac.rs, ORCID: http://orcid.org/0000-0002-9532-810X

2 Mlađan Dimitrijević, General manager, Student Center Kragujevac, Radoja Domanovića 12, Kragujevac, Serbia, Phone: +38134336065, E-mail: office@studentskicentar-kg.rs, ORCID: http://orcid.org/ 0000-0002-2858-8921 
production practices that will, in the long term: meet people's food needs, improve the quality of the environment and natural resources on which the agricultural economy depends, enable the efficient use of non-renewable and renewable resources, enable the natural biological cycles to unfold, sustain the economic value of production, and improve the quality of life of farmers and society as a whole.

Consumers also play an important role in creating a sustainable food production system. Through demand, they send a strong message to manufacturers, sellers, and other supply chain actors about what is important to them. The price of agricultural products, as well as their nutritional value and quality have always had a decisive influence on consumer choice. The challenge today is to find a strategy that will develop customer awareness, so that preserving resources, the environment and social justice are one of the decisive motives for buying. At the same time, new regulations, laws and interventions by state institutions must enable sustainable agricultural production to have adequate market operations and access to the general public.

Research objectives are:

1. Determine whether, when purchasing food, consumers take into account its organic origin;

2. Explore the reasons why residents of the Šumadija region use organically produced food;

3. Determine the degree of familiarity of the residents of the Sumadija region with the difference between organically produced food and food produced in the conventional way;

4. Examine how residents of the Šumadija region are informed about the benefits of using organically produced food;

5. Examine residents' motives for purchasing organically produced food;

6. Explore where residents buy organically produced food in the Šumadija region;

7. Examine the degree of satisfaction of the people from the Šumadija region with the range of organically produced food in their region.

Research hypotheses are defined as:

1. Residents of the Šumadija region prefer to buy organic products, with particular buying habits, information and satisfaction regarding these products.

2. Consumers' behavior in the Šumadija region in relation to organic products is conditioned by their socio-demographic characteristics.

\section{Literature Review}

The Sumadija region is located in the central part of the Republic of Serbia, between rivers Sava and Danube in the north, Velika Morava in the east, West Morava in the 
south and Kolubara in the west. The area of the region is $2.387 \mathrm{~km}^{2}$, of which $835 \mathrm{~km}^{2}$ is the territory of the City of Kragujevac, which is also the largest city in the entire region. The population of the Sumadija region is 298.778 people and the average population density is 125 inhabitants $/ \mathrm{km}^{2}$. The city of Kragujevac is the largest city on the territory of Šmadija, and it is also the administrative, economic, cultural, educational and health center of the entire region of Sumadija and central Serbia. It is located in the central part of the Republic of Serbia and the Šumadija region, $140 \mathrm{~km}$ southeast of Belgrade.

Šumadija region is located in the central part of Serbia, in the area of numerous local watercourses. Natural conditions favor the development of different agricultural systems. The alluvial plains in the river valleys favor the development of arable crops and vegetable gardens, and are more favorable to the development of viticulture and fruit growing. The land is mostly used for arable land, orchards and vineyards, but there are also meadows, pastures and forest areas.

If we look at the structure of agricultural land in the Šumadija region, we can conclude that the most dominant are arable land and gardens, which cover $69 \%$ of the total agricultural area. Here, the area under cereals, which accounts for $40.8 \%$ of the total agricultural area of the region, should be singled out. In the overall structure of agricultural land in the region, orchards cover $9.2 \%$ of the area. A negligibly small percentage in the structure of agricultural land covers areas under vineyards $-2 \%$ of the agricultural area of the entire region.

According to the latest official census conducted in 2012, 64062 inhabitants live in the municipalities of Sumadija related to agricultural activities, or $12.2 \%$ of the total population of the region. Of this number, two thirds of the population is active agricultural population. Comparing this data with data at the republican level, it can be observed that the percentage share in the region is slightly higher than the republican one. Namely, the agricultural population in the total population of the Republic of Serbia participates with $10.9 \%$, of which the active agricultural population makes $64.8 \%$.

Šumadija has abundant natural capacities, which are a good basis for the future development of organic agriculture, since natural resources are scarce. The composition and structure of natural resources are very favorable. Šumadija has relatively unpolluted land, favorable climate and rich water potential and preserved biodiversity, which all together are basic prerequisites for dealing with organic agriculture.

Organic food production is an extremely promising activity that is receiving considerable attention in the developed countries. It is embedded in national strategies and the demand for healthy food is intensifying year by year. Increasing consumption of organic agri-food products leads to the preservation of health, and environmental protection.

There are numerous studies on the reasons for using organically produced food in the world. Thus, Magetts et al (1997) placed special emphasis on research into the impact of respondents' educational attainment on healthy food choices, and the result indicated that this was the strongest influence factor. The authors also pointed to a significant 
number of respondents who knew nothing about healthy food, which clearly indicated the need for their education. In contrast, Grunert and Juhl (1995) presented research findings with Danish school teachers regarding their values, environmental attitudes, and organic food purchasing. The aim was to examine the application of value theory and measurement approaches in explaining specific aspects of consumer behavior.

Hendrik et al (1998) compared the determinants of organic food consumption, based on a sample of shoppers from health food stores versus those in a nationally representative household. Organic food customers are considered to be more responsible for their own health and to have taken preventative health measures more often than the general population. The absence of pesticides, the environment and better taste were the main reasons for buying organic food. Discriminant analyses have shown that the difference between these two customer groups indicates that organic food consumption is in fact part of a lifestyle that results from a specific ideology, linked to a particular value system. A similar survey was conducted by Cowan (1998), on a large sample of European Union consumers, with $60 \%$ of them saying that they were very concerned about the quality of the meat they were offered. The majority of respondents stated that the price of meat does not play a decisive role in the purchase, but a confidence in the health safety of food. The same research also pointed to the encouraging fact that more than half of younger respondents are aware of the health hazards that the consumption of meat produced by intensive agriculture can have.

Results of the study by Fotopoulos et al. (1999) have shown that a lack of knowledge is a key problem hampering the momentum of health food development in the future, and education at all levels suggested by competent educators is suggested. as the first and basic measure of improvement. In contrast, Toriusen et al (2001), exploring the potential of organic agriculture, are convinced that it is very important to inform consumers and producers about food quality and systemic issues. Their analysis showed that traditional aspects of food quality, such as freshness and taste, were very important to consumers, and those buying organic food were more concerned with environmental and health issues and identified consumer orientations in the food market. Survey results in the UK indicated the reasons of respondents to buy or not to buy healthy food. It has been found that $36 \%$ of consumers consider the promotion of personal health as the primary motive for purchasing healthy food, $31 \%$ opt for better taste and $25 \%$ consider food origin (Hallam, 2002).

Stolz et al (2011) conducted a survey aimed at isolating casual organic consumers given their preferences for organic and conventional products. In addition, the aim was to analyze differences between consumption in segments in terms of their sensitivity to prices and attitudes towards food. Different segments were identified and the conclusion was that communicating quality product features is a promising marketing tool for product differentiation for both organic and conventional foods.

By analyzing the attitudes, motivations, demographics and consumer behavior factors that influence food choices among Australian consumers who have consumed at least 
some organic food in the previous 12 months, Stevart Lockie et al (2004) found that organic food quality and emotional consumer experience were the main determinants of increasing organic food consumption. Increasing consumption is also related to other behaviors of the so-called green spending such as recycling and, at lower levels, concerns about buying and preparing food itself. Most of these factors, in turn, are strongly influenced by gender and the responsibility of women for providing food in their households. Education has even had a negative impact on this behavior due to the lower level of education of women, and - interestingly - income, age, political views and environmental values and willingness to pay for safe and organic food have had very little effect. A study by Tsakiridou et al (2008) concluded that Greeks as consumers are informed about environmental and health issues. They seek information on the nutritional value of foods and require products that are free of chemical additives. The results showed that the majority of consumers perceive organic food as fruits and vegetables and that, although certain demographic characteristics indicate a link with the consumption of these foods, in this study their interrelationships were not significant.

Regarding research in Serbia, Dašić et al (2019) conducted a study on the importance and value of organic products in the opinion of customers, their buying habits, their source of information or their level of knowledge and satisfaction with organic products. The results showed that there are different buying habits of organic products. The differences between the customers are expressed on the basis of their way of informing about organic products, the reasons for buying organic products, their needs for product quality in the market and according to the place of purchase of organic products. Consumer habits of different gender and age, status, education and place of residence were also found to be very different. Women are more likely to use information from the electronic media, other people, and professional literature, while men are more likely to use the journal for information on the characteristics of organic products. Also, customers under the age of 30 and those between 41 and 50 mainly use the Internet and other electronic media. The authors also concluded that most consumers in Serbia preferred to use organic products over conventional products. They buy organic products in various places: supermarkets, markets and specialty stores. A significantly small number of customers buy organic products directly from producers or online. Customers' decision to buy organic products was influenced the most by the reliability of the producers, and the least by the locations.

Zaric \& Vasiljevic (2007) pointed out that in the Western European countries most of the organic products are sold through supermarkets, while it is estimated that specialized stores are the most important for traffic in Serbia. There are conditions for organic production in Serbia, but producers are currently showing little interest. Domestic demand is low, primarily due to the lack of consumer information, but also due to the lack of confidence in quality.

By researching consumers' attitudes about organic food consumption in Serbia, Vlahovic et al (2011) concluded that three quarters of the respondents are not familiar with the organic food law. In addition, more significant consumer education is needed http://ea.bg.ac.rs 
in this direction in order for them to be better informed and for the demand to be increased. Most respondents (40\%) have confidence in domestic organic products, which is a good basis for increasing market supply. The majority of respondents buy organic agricultural products from the markets (40\%). It was noted that the importance of specialized organic food shops is decreasing. Half of the respondents believe that organic agricultural products have a high price, which is a significant limiting factor in increasing demand and consumption. Almost half of those surveyed are willing to pay more to buy organic products.

Vlahovic \& Sojic (2016) concluded that in the Republic of Serbia there is an increasing interest in organic agri-food products. Respondents' good information and health concerns largely determine the decision to allocate more resources to the purchase and consumption of organic food. The price and the level of income of the respondents represent the basic limiting factors of demand for organic agri-food products. The low purchasing power of the population makes it difficult for consumers to increase their high nutrition expenditures by purchasing more expensive organic products. Organic food producers need to make branding a marketing activity that will have a competitive edge in the market. In this way, customer loyalty is created and sales are increased and thus better financial results are achieved.

\section{Methodology of the Research}

The following methods were used to investigate the use of organically produced food by the inhabitants of the Šmadija region: theoretical analysis and synthesis method and descriptive method. The method of theoretical analysis and synthesis generalizes and formulates the most important findings from empirical research, and it is best suited to set the framework and basis of any research. This method determines the goal, tasks and other elements of empirical research. The descriptive method is used to describe the obtained results, based on the stated opinions of the respondents. It is the most commonly used method in social science research, as it describes the phenomena under study and thus introduces them more closely to their essence, the interdependence with other phenomena. It was used here to collect process and interpret data. The data obtained by the survey were processed qualitatively and quantitatively in percentages, and the results of the survey were given in textual and graphical form.

The popularity of organic food is measured by the increase in sales, which has increased by over 5\% annually in recent years. Larger global markets such as the US estimate that organic food accounts for about $4 \%$ of total annual food sales, and forecasts for next year suggest organic fruit and vegetable sales could grow by a fantastic 14\%. In Western Europe and the Americas, surveys show that consumers' main reasons for using organic food are its potential contamination, cost and environmental protection during production. For the purpose of researching the use of organically produced food in the inhabitants of the Sumadija region, the target group were the citizens of Kragujevac. The survey included 100 citizens of the city of Kragujevac of all age. The survey was conducted through a systematic questionnaire, which was filled in by the citizens on the spot. 
Based on the gender structure of the participants in this survey, we can conclude that there were more female respondents $(52 \%)$ than male respondents $(48 \%)$. As this research included the use of organically produced food in the inhabitants of the Šmadija region, the age structure of the respondents as well as gender was a relevant indicator for this research, so the citizens of all age groups participated in the survey.

The results on the age of the respondents showed that the majority of citizens were aged 26 to 40 (28\%), followed by the respondents between 41 and $50-(24 \%)$. The youngest respondents, between 18 and 25, made $21 \%$, followed by respondents between 51 and $65,(14 \%)$, while the smallest number of respondents were in the oldest age group over $65(13 \%)$. We can also conclude that the younger population was most happy with this survey, so that a larger number of respondents belongs to the younger population.

\section{Results}

The first question asked to the people of the Šumadija region was whether they were considering organic origin when buying food. The answers were presented by gender and age of the survey participants. The data obtained suggested that many more female residents take care of organic origin when shopping compared to male residents, because only 12 of male residents stated that they took care of organic origin. The results showed that when buying food, most organic consumption is taken into account by consumers between the ages of 26 and 40, while the youngest residents, or the youngest participants in the survey, take the least care, since more than $60 \%$ of the youngest respondents make no difference and never care. The oldest surveyed residents usually always or sometimes worry about the organic origin of the food they buy.

The next thesis of this research was to examine the reasons why it is important that the foods we consume are of organic origin. Based on the results of this part of the research, we can conclude that female respondents generally have a positive opinion about organically produced food compared to male respondents; that is, most female respondents stated that they want to eat healthy and that they can control their healthy diet, and that conventional food production is detrimental to health due to the addition of additives and preservatives. 
Figure 1. Reasons for consuming organic food by age

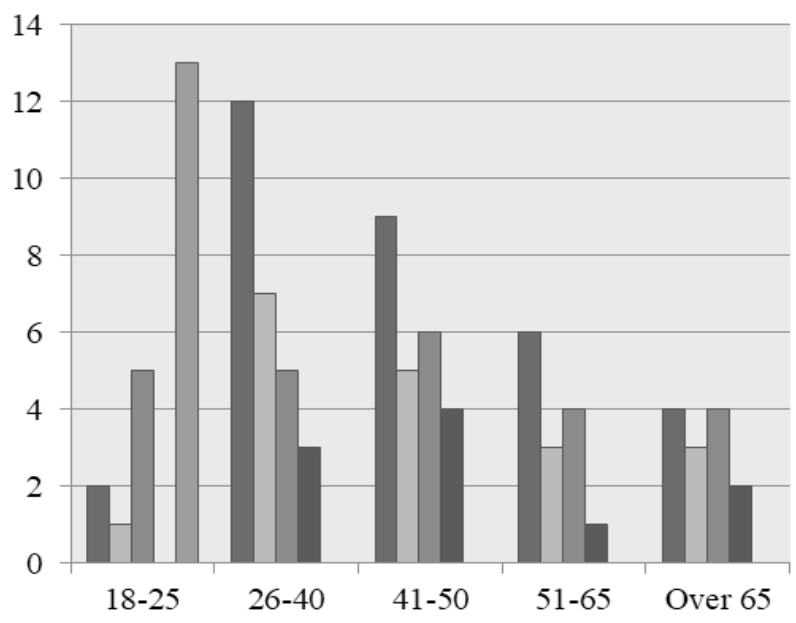

घecause I want to eat healthy

$\square$ conventional foods are harmful to health

$\square$ healthy foods can control health

on the recommendation of a physician

$\square$ it doesn't matter to me

Source: Author's calculation

Male respondents have the most answers that it does not matter if the food they consumed was of organic origin. The most important thing to the residents between 26 and 40 as well as to the oldest survey participants is that their food is of organic origin while the youngest participants (belonging to the age between 18 and 25) do not care whether the food they consume is of organic origin. The oldest survey participants, as well as those between 51 and 65, generally take care of consuming organic foods.

The next hypothesis was about exploring the extent to which respondents are aware of the difference between organically produced food and food produced in the conventional way. The majority of respondents (predominantly female) were aware of the differences between organically produced food and food produced in a conventional way and the majority of those who were not aware were among the youngest among the male population surveyed.

Respondents between 41 and 50 years of age, and largely residents between 26 and 40, are fully aware of the differences. The majority of those unfamiliar with the differences between organically produced food and food produced in the conventional way belong to the age group between 18 and 25, while the older population surveyed is largely aware of the differences. 
Figure 2. Method of informing the respondents about the benefits of using organically produced food by age

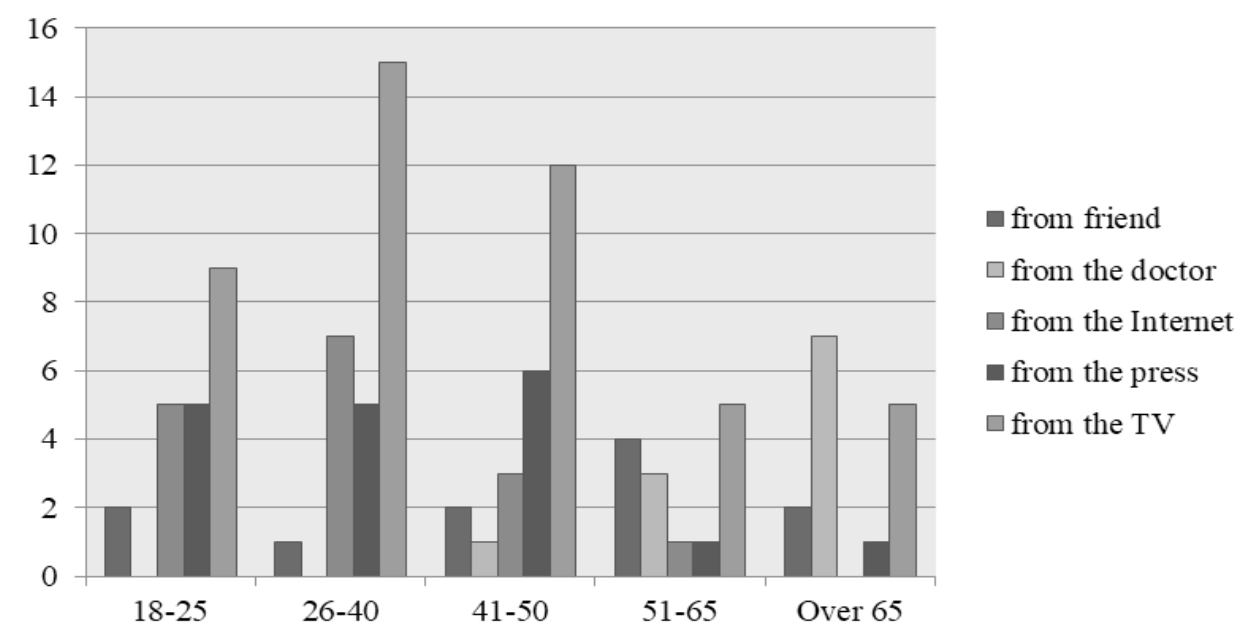

Source: Author's calculation

The next aim of the survey was to examine how the surveyed citizens are informed about the benefits of using organically produced food. Almost half of the respondents received information about healthy food and the benefits of healthy nutrition through television (46\%), then through the press, referring to daily and weekly press $(18 \%)$, then via the Internet or electronic media (14\%), health clinics, i.e. from doctors (11\%) and from friends $(11 \%)$.

When it comes to informing on the health benefits of respondents by age, the results show that the youngest surveyed population accesses information most often via television and the Internet, as do residents between the ages of 26 and 40. In addition to television, the elderly population most often uses print media or friendly advice in addition to television, and the oldest population, over 65 years of age, receive most information in health care dispensaries, by doctors. Overall, television is the most popular medium through which the population receives all the necessary information about the benefits of using organically produced food.

The next hypothesis was to examine the motives of the inhabitants of the Sumadijaregion for the use of organically produced food. More than half of them (57\%) cite a healthy life as their primary motive, then a fact that there are no chemical substances $(20 \%)$, and that they want to control the disease through organic nutrition. There is no difference in the gender response of the interviewed citizens. The youngest residents cite healthy living as the main motive for using healthy food, the same as the other age groups of the respondents, while $4 \%$ of them indicate that using healthy nutrition follows current world trends. 
Figure 3. Motives for buying organically produced food by age

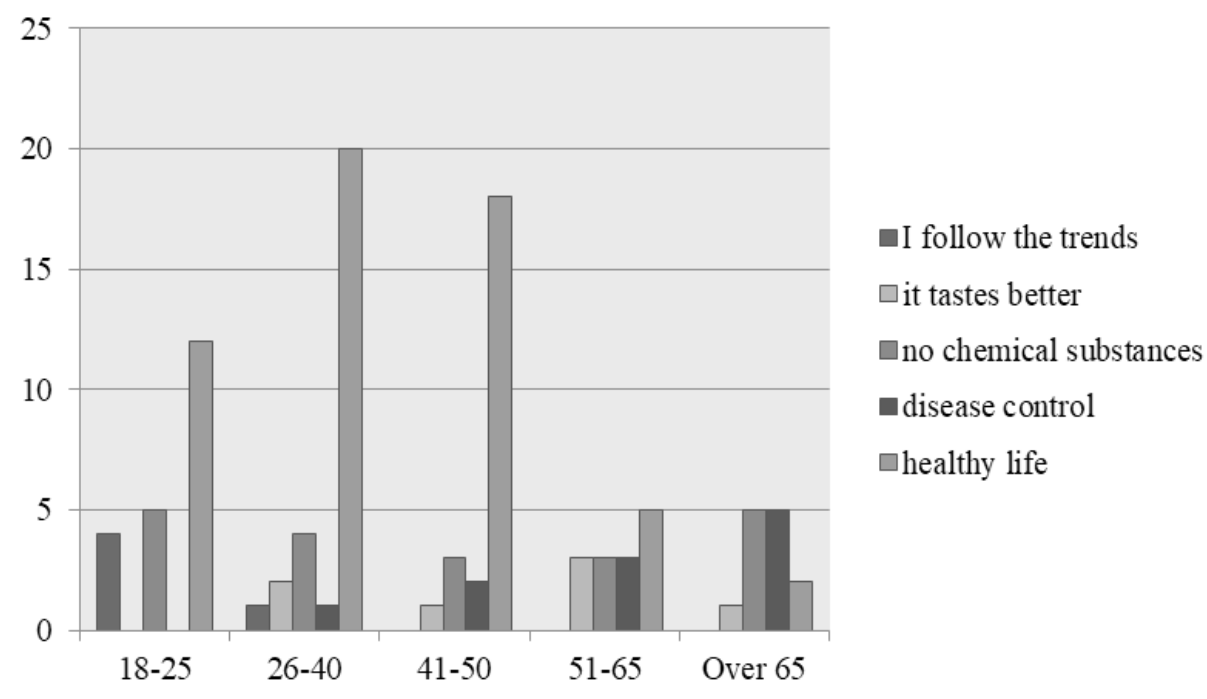

Source: Author's calculation

The next hypothesis of the research concerned the places of purchase of organically produced food. The results show that the surveyed citizens mostly buy their food at markets and supermarkets - $38 \%$, then in health food stores, and on farms. It is noticeable that men buy healthier food much more in supermarkets, while women buy it at markets.

The youngest population mostly purchases organically produced food in supermarkets, unlike the oldest population who purchases this kind of food mainly at markets and health food stores. Health food stores are mostly visited by the population between 26 and 40 years of age, as well as between 41 and 50 years of age.

The next question we wanted to explore is whether the citizens of the Šumadija region are satisfied with the presence and availability of organically produced food on the domestic market and the results show that $28 \%$ of respondents are completely satisfied, $14 \%$ are largely satisfied, $30 \%$ are mostly satisfied. No noticeable differences were observed in the responses examined by gender. The highest level of dissatisfaction with the availability and representation in the healthy food market was recorded among the 26 to 40-year-old population, while the least dissatisfied was the older population of the surveyed citizens. The most satisfied were the residents of the Šumadija region between 41 and 50, as well as between 51 and 65 years of age. 
Figure 4. Place of purchase of organically produced food by age

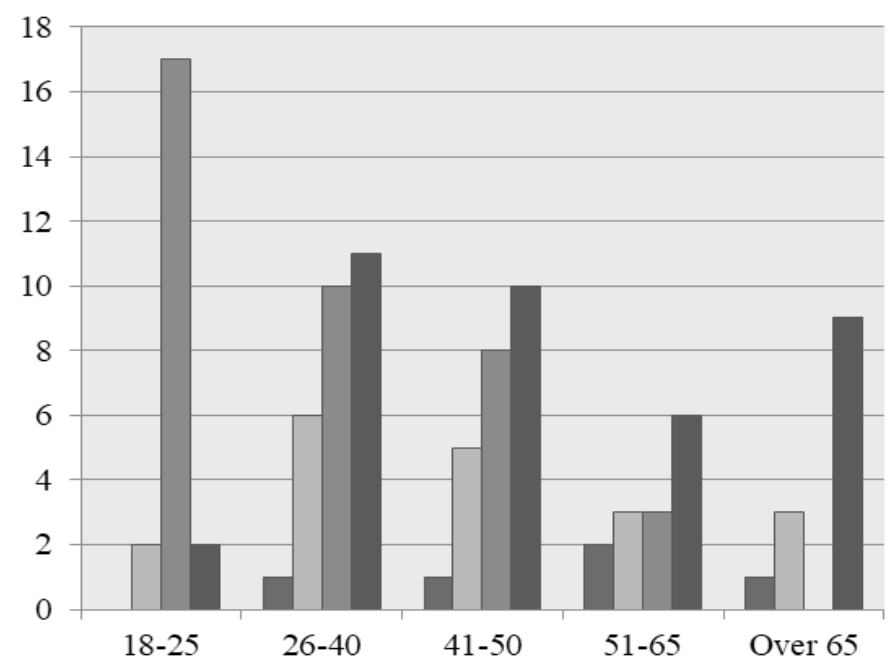

non farms

$\square$ at health food stores

$\square$ in supermarkets

an the market

\section{Source: Author's calculation}

The last hypothesis of the research concerned the level of satisfaction with the range of organically produced food in the domestic market. The obtained results show that most of them stated that they were dissatisfied with the range (31\%), 27\% were partially satisfied with the range, and $23 \%$ were very satisfied. The most dissatisfied were females, while the male respondents were partially satisfied. Citizens of the younger population as well as the population between 26 and 40 were the least satisfied with the assortment, while those aged 41 to 50 were the most satisfied with the assortment.

\section{Discussion}

According to the results of the survey, residents of the Šmadija region buy organic food mainly because they understand its role in reducing health risks $(33 \%)$, as confirmed by the findings of a 2002 study by Hallam (2002), which indicate that $36 \%$ of consumers have the promotion of personal health as the primary motive for buying healthy food. Similar results were obtained by Magnusson et al (2003) in a study regarding attitudes and behavior towards organic food, environmental behavior and estimated consequences of organic food choices in terms of human health, environment and animal welfare in a sample of 2000 Swedish citizens, aged 18 to 65. Similar to the UK study (2002) mentioned above, the strongest link between buying organic food is due to the perceived benefit to human health. A 2016 survey by Vlahovic \& Sojic showed that, among the surveyed consumers, the first concern is health. $44 \%$ of respondents stated that this was their most important reason, 15\% emphasized health as an important factor, and only $2 \%$ considered that health was not important factor when buying organic agri-food products. 
The next most important reason to buy was the belief that food tastes better, followed by those who consider organic food more natural and those who want to avoid genetically modified products. Similar results were shown by a study by Wier et al (2008) in which the authors examine organic food markets in the UK and Denmark, identifying major differences and similarities in consumer perceptions and priorities. The authors found that organic food purchasing decisions were primarily motivated by attributes such as freshness, taste, and health.

The results showed that the surveyed citizens mostly buy food at markets and supermarkets - 38\%, then in health food stores and on farms. Zaric \& Vasiljevic (2007) stated that in Western European countries most organic products are sold through supermarkets, while the assessment is that specialized stores are the most important in Serbia. A significantly lower proportion of respondents (14.7\%) stated that they would acquire the same directly from the manufacturer (on the farm or home delivery), while online shopping had a negligible share of $0.2 \%$.

The youngest residents cite healthy living as the main motive for using healthy food, the same as the other age groups of the respondents, while $4 \%$ of them indicate that using healthy nutrition follows current world trends. A study by Vlahović \& Šjić (2016) found that there was no significant correlation between organic food purchases and respondents' age categories, meaning that respondents of all age categories were equally buying organic foods. There is a significant correlation between the amount of income and the purchase of organic agri-food products: higher income respondents buy organic agri-food products more. With rising living standards, demand for organic products can be expected. Also, a significant correlation between educational attainment and purchase of organic agri-food products has been found in the study.

Given the dominance of price and quality in the decision to purchase these products, it is imperative that manufacturers focus more on consumers who are already "more environmentally conscious and more concerned about health" because of proven product provenance, attractive packaging and the fact that the product is more environmentally friendly. Respondents who have tried organic food products are more concerned about calories, prefer to buy home-made food products, eat mostly fresh foods compared to respondents who have not tried organic food products, and are likely informed about a healthy lifestyle.

Consumption of organic agri-food products is based on public awareness of the increasing pressures of environmental problems. The introduction of an incentive strategy to consume organic products is thought to contribute to their increased use (Grant, 2007).

Supermarkets have made a major contribution to the promotion of the organic sector, because it is only when supermarkets have included organic products in their product range that sales of these products have become popular. The domestic organic market is small and underdeveloped. Organic products can be purchased in a small number of specialized stores, farms and wholesale. 
The characteristics of the Šumadija organic product market are: the largest number of imported products, retail sector underdevelopment, uninformed consumers, unrecognizable labels organic product, fake products.

The Sumadija market was selling products that were promoted as organic, and they were not at all. As a result, consumers have become skeptical when it comes to purchasing organic products. This should be tackled by introducing more frequent inspection controls and paying high fines for impersonation of products, in order to protect consumers and organic food producers. Organic food will not become popular in our country for many reasons: consumer ignorance, low purchasing power, low availability of organic products in the domestic market that are not sufficiently represented through sales channels, higher prices for some products, relatively healthy conventional food, etc.

\section{Conclusion}

Šumadija has rich natural capacities which are a good basis for the future development of organic agriculture. The composition and structure of natural resources is very favorable. Šumadija has relatively unpolluted land, a favorable climate and rich water potential and preserved biodiversity, which all together are basic prerequisites for dealing with organic agriculture. Organic production is not possible if there is no minimum required conservation of natural resources in the areas where production is organized, while on the other hand, the organic production process has a positive effect on the conservation and improvement of the environmental quality of these areas.

Given that the organic market in Šumadija is underdeveloped, the role of marketing is of paramount importance. In this context, marketing in our conditions should be understood not only as activities undertaken by one producer or group of producers in order to bring their products closer to as many customers as possible, but as one of the general measures to support the development of the entire organic sector in Serbia. In this context, marketing can be seen as a way of developing the awareness of the general population as potential consumers about the importance of organic production and the characteristics of organic products.

Increasing demand for organic products is directly conditioned by consumers' eating and shopping habits. Changing habits is directly conditioned by the level of consciousness development. Food producers and distributors, with the help of government, faculty, organic food associations, the media, can influence the behavior and culture of consuming organic food. An important element in developing consumer awareness of organic production and products concerns their recognition. At the same time, recognizability means both a clearly visible and specific sign marking of an organic product, as well as a distinctive point of sale. Another important point in enhancing the consumption of organic products in our country concerns the guarantee of product quality; that is, consumer confidence in producers and control systems. Also, market supply is a significant factor in boosting demand for organic produce. Namely, the wider distribution of these products, as well as their more diverse offerings, with clear 
recognition, provides better accessibility to consumers, and thus has the potential to boost their demand.

The main retail outlets are markets, health food stores and supermarkets. Supermarkets have a small share of sales today; however, it is certain that organic food will increasingly be sold in large supermarket chains that are likely to target customers who consume organic food for health reasons, while smaller regional stores will focus on shoppers of organic food for philosophical reasons.

\section{Conflict of interests}

The authors declare no conflict of interest.

\section{References}

1. Cowan, C. (1998). Irish and European Consumer Views on Food Safety. Journal of Food Safety, 18(4), 275-295.

2. Dašić, G., Radosavac, A., Knežević, D. \& Đervida, R. (2019). Preferences of customers and improvement of production and sales of organic products in Serbia. Economics of Agriculture, 66(1), 127-142.

3. Fotopoulos, C., Chryssochoidis, G. \& Pantzios, J. (1999). Critical factors affecting the future of the Greek market of organic produce, Rivista di Economia, Agricoltura e Ambiente, 3, 30-35.

4. Grant, J. (2007). The Green Marketing Manifesto. John Wiley \& Sons Ltd, England.

5. Grunert, C. \& Juhl, J. (1995). Values, environmental attitudes, and buying of organic foods. Journal of Economic Psychology, 16, 39-62.

6. Hallam, D. (2002). The organic market in OECD Countries: Past Growth, current status and Future Potential. OECD Workshop on Organic Agriculture, Washington D.C., USA.

7. Hendrik, J., Schifferstein, J. \& Oude Ophuist, M. (1998). Health-related de terminants of organic food consumption in the Netherlands. Food Quality and Preference. 9(3), 119-133.

8. Magetts, B., M., Martinez, J., A., Saba, A., Holm, L. \& Kearney, M. (1997). Definitions of Consumer Attitides to Food, Nutrition and Health. European Journal of Clinical Nutrition, 51(2), 23-29.

9. Magnussona, K., Arvolaa, A., Koivisto Hurstia, K., Abergb, L. \& Per-Olow Sjöden, O. (2003). Choice of organic foods is related to perceived consequences for human health and to environmentally friendly behavior. Appetite, 40, 109-117.

10. Stewart Lockie, S., Lyonsb, K., Lawrence, J. \& Grice J. (2004). Choosing organics: a path analysis of factors underlying the selection of organic food among Australian consumers. Appetite, 43, 135-146. 
11. Stolz, H., Stolze, M., Hammb, U. Janssenb, M. \& Rutoc, E. (2011). Consumer attitudes towards organic versus conventional food with specific quality attributes. NJAS - Wageningen Journal of Life Sciences, 58, 67-72.

12. Torjusen, H., Lieblein, G., Wandel, M. \& Francis, C. (2001). Food orientation and quality perception among consumers and producers of organic food in Hedmark County, Norway. Food Quality and Preference, 12, 2017-216.

13. Tsakiridou, E.,Boutsouki, C.,Zotos, Y. \& Mattas, K. (2008). Attitudes and behaviour towards organic products: an exploratory study. International Journal of Retail \& Distribution Management, 36(2), 158-175.

14. Vlahović, B. \& Šojić, S. (2016). Exploring consumer attitudes about organic agri-food products and their brands. Agrieconomica, 45(70), 33-46. [In Serbian: Istraživanje stavova potrošača o organskim poljoprivredno-prehrambenim proizvodima i njihovim brendovima]

15. Vlahović, B., Radojević, V. \& Živanić, I. (2011). Survey of Consumer Attitudes on Organic Food Consumption in Serbia. Economics of Agriculture, 58(3), 441-456. [In Serbian: Istraživanje stavova potrošača o potrošnji organske hrane u Srbiji]

16. Wier, M., O’Doherty Jensen. K., Mørch Andersen, L. \& Millock, K. (2008). The character of demand in mature organic food markets: Great Britain and Denmark compared. Food Policy. 33, 406-421.

17. Zarić, V. \& Vasiljević, Z. (2007). Possibilities to analyze the international competitiveness of organic products from Serbia. Thematic proceedings Multifunctional Agriculture and Rural Development, Institute for Agricultural Economics, Belgrade, 105-112. [In Serbian: Mogućnosti analize međunarodne konkurentnosti organskih proizvoda iz Srbije] 